TITLE:

\title{
A Hydronium Solvate Ionic Liquid: Ligand Exchange Conduction Driven by Labile Solvation
}

\section{$\operatorname{AUTHOR}(\mathrm{S}):$}

Kitada, Atsushi; Kintsu, Kohei; Takeoka, Shun; Fukami, Kazuhiro; Saimura, Masayuki; Nagata, Takashi; Katahira, Masato; Murase, Kuniaki

\section{CITATION:}

Kitada, Atsushi ... [et al]. A Hydronium Solvate Ionic Liquid: Ligand Exchange Conduction Driven by Labile Solvation. Journal of the Electrochemical Society 2018, 165(9): H496H499

\section{ISSUE DATE:}

2018

URL:

http://hdl.handle.net/2433/233922

\section{RIGHT:}

(c) The Author(s) 2018. Published by ECS. This is an open access article distributed under the terms of the Creative Commons Attribution 4.0 License (CC BY, http://creativecommons.org/licenses/by/4.0/), which permits unrestricted reuse of the work in any medium, provided the original work is properly cited. 


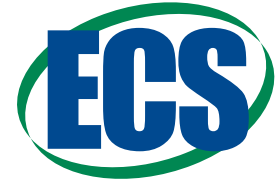

\title{
A Hydronium Solvate Ionic Liquid: Ligand Exchange Conduction Driven by Labile Solvation
}

\author{
Atsushi Kitada, ${ }^{1, z}$ Kohei Kintsu, ${ }^{1}$ Shun Takeoka, ${ }^{1}$ Kazuhiro Fukami, ${ }^{1, *}$ \\ Masayuki Saimura, ${ }^{2}$ Takashi Nagata, ${ }^{2}$ Masato Katahira, ${ }^{2}$ and Kuniaki Murase ${ }^{1, *}$ \\ ${ }^{1}$ Department of Materials Science and Engineering, Kyoto University, Sakyo, Kyoto 606-8501, Japan \\ ${ }^{2}$ Institute of Advanced Energy, Kyoto University, Gokasho, Uji, Kyoto 611-0011, Japan
}

\begin{abstract}
We observed a new class of proton conduction in a hydronium $\left(\mathrm{H}_{3} \mathrm{O}^{+}\right)$solvate ionic liquid (IL). The IL is described as $\left[\mathrm{H}_{3} \mathrm{O}^{+} \cdot 18 \mathrm{C} 6\right] \mathrm{Tf}_{2} \mathrm{~N}$, composed of 18-crown-6-ether (18C6)-coordinated $\mathrm{H}_{3} \mathrm{O}^{+}$cation (solvate) and bis(trifluoromethylsulfonyl)amide $\left(\mathrm{Tf}_{2} \mathrm{~N}^{-}\right.$; $\left.\mathrm{Tf}=\mathrm{CF}_{3} \mathrm{SO}_{2}\right)$ anion. Self-diffusion coefficient measurements revealed that protons of $\mathrm{H}_{3} \mathrm{O}^{+}$(solute ion) move faster than 18C6 ligand (solvent), marking the first observation of ligand exchange conduction not only among solvate ILs but also among protic ILs without free neutral molecules. The presence of ligand exchange conduction without inducing external electric field indicates that solvation of $\mathrm{H}_{3} \mathrm{O}^{+}$by $18 \mathrm{C} 6$ is kinetically labile, i.e. ligand exchange is very fast for the reaction $\mathrm{H}_{2} \mathrm{O}+18 \mathrm{C} 6+\mathrm{HTf}_{2} \mathrm{~N} \rightleftharpoons\left[\mathrm{H}_{3} \mathrm{O}^{+} \cdot 18 \mathrm{C} 6\right] \mathrm{Tf}_{2} \mathrm{~N}$, while the equilibrium shifts to the right. The fundamental findings regarding the hydronium solvate IL will help in the design of proton conductors.

(c) The Author(s) 2018. Published by ECS. This is an open access article distributed under the terms of the Creative Commons Attribution 4.0 License (CC BY, http://creativecommons.org/licenses/by/4.0/), which permits unrestricted reuse of the work in any medium, provided the original work is properly cited. [DOI: 10.1149/2.0971809jes]

(cc) BY
\end{abstract}

Manuscript submitted April 18, 2018; revised manuscript received May 31, 2018. Published June 13, 2018

Ionic liquids (ILs) are liquid compounds, which consist only of cations and anions and melt below $100^{\circ} \mathrm{C}$. ILs have received growing interest due to their various uses as media in chemical, biochemical and/or electrochemical systems. ${ }^{1-6}$ ILs are classified as aprotic ILs, protic ILs, solvate ILs, and inorganic ILs. ${ }^{7}$ Solvate ILs are often represented by equimolar molten mixtures of oligoethers (glymes) and certain metal salts, where Lewis acidic metal cations are solvated by equimolar amount of Lewis basic glymes to give complex cations. ${ }^{8-15}$ On the other hand, protic ILs are prepared through neutralization of Brønsted acids and bases. ${ }^{3-6}$ For instance, a binary mixture of an "imide" superacid, bis(trifluoromethylsulfonyl)imide $\operatorname{HTf}_{2} \mathrm{~N}$ ( $\mathrm{Tf}=$ $\mathrm{CF}_{3} \mathrm{SO}_{2}$ ), and a base imidazole (Im) gives protonated imidazolium $\left(\mathrm{ImH}^{+}\right.$) cations and $\mathrm{Tf}_{2} \mathrm{~N}^{-}$anions to form protic ILs. ${ }^{16,17}$ Protic ILs are preferred as acid-catalyzed reaction media due to the presence of an acidic proton. ${ }^{3-6}$

More recently, we reported for the first time a hydronium $\left(\mathrm{H}_{3} \mathrm{O}^{+}\right)$ solvate $\mathrm{IL},\left[\mathrm{H}_{3} \mathrm{O}^{+} \cdot 18 \mathrm{C} 6\right] \mathrm{Tf}_{2} \mathrm{~N}$, which intersect solvate ILs and protic ILs. ${ }^{18}$ Figure 1a presents the structural formula; here, water exists as hydronium $\left(\mathrm{H}_{3} \mathrm{O}^{+}\right)$ion (i.e. solute ion), $18 \mathrm{C} 6$ as a ligand (i.e. solvent) to form $\left[\mathrm{H}_{3} \mathrm{O}^{+} \cdot 18 \mathrm{C} 6\right]$ complex cation (i.e. solvate), of which the counter anion is $\mathrm{Tf}_{2} \mathrm{~N}^{-}$anion, a dissociated species of $\mathrm{HTf}_{2} \mathrm{~N}$. The hydronium solvate IL is the first example of a nonmetalcation-solvate IL, which melts at rather low temperature of $68-70^{\circ} \mathrm{C}$ (Fig. 1b), compared with the known $\left[\mathrm{H}_{3} \mathrm{O}^{+} .18 \mathrm{C} 6\right]$ complexes with common anions of ILs such as $\mathrm{ClO}_{4}^{-}, \mathrm{SbF}_{6}{ }^{-}, \mathrm{PF}_{6}{ }^{-}, \mathrm{TfO}^{-}, \mathrm{BF}_{4}^{-}, \mathrm{FeCl}_{4}{ }^{-}$ (ca. $\left.110-170^{\circ} \mathrm{C}\right) .{ }^{19-22} \mathrm{We}$ confirmed that the hydronium complex $\left[\mathrm{H}_{3} \mathrm{O}^{+} \cdot 18 \mathrm{C} 6\right] \mathrm{Tf}_{2} \mathrm{~N}$ satisfies the criteria of a solvate IL, ${ }^{8}$ containing a negligible number of neutral molecules.

Since the stability constant $K$ for $\left[\mathrm{H}_{3} \mathrm{O}^{+} \cdot 18 \mathrm{C} 6\right]$ in acetonitrile shows $\log K=6.5,{ }^{23}$ such strong solvation could give a vehicle mechanism for ionic conduction of $\left[\mathrm{H}_{3} \mathrm{O}^{+} \cdot 18 \mathrm{C} 6\right]$, where $\mathrm{H}_{3} \mathrm{O}^{+}$and the 18C6 ligands would move together, as well as "usual" solvate ILs, where metal ions (such as lithium ions) and the ligands does so. ${ }^{8-10}$ To address this issue, the conduction mechanism of the hydronium solvate IL must be studied in detail. In this paper, we conducted ${ }^{1} \mathrm{H}$ and ${ }^{19} \mathrm{~F}$ PGSE-NMR measurements to determine the self-diffusion coefficients of $\mathrm{H}_{3} \mathrm{O}^{+}, 18 \mathrm{C} 6$ ligand, and $\mathrm{Tf}_{2} \mathrm{~N}^{-}$anions in the molten state. The obtained self-diffusion coefficients the hydronium solvate IL were compared to previous solvate ILs and protic ILs.

\section{Experimental}

The synthesis of $\left[\mathrm{H}_{3} \mathrm{O}^{+} \cdot 18 \mathrm{C} 6\right] \mathrm{Tf}_{2} \mathrm{~N}$ is described in our previous report. ${ }^{18}$ The pulsed-field gradient spin echo NMR (PGSE-NMR) measurements were performed at $75^{\circ} \mathrm{C}$ and $85^{\circ} \mathrm{C}$ using JNM-ECA600 NMR spectrometer (JEOL Ltd.). The ${ }^{1} \mathrm{H}$ and ${ }^{19} \mathrm{~F}$ spectra were measured. Other basic experimental conditions were the same as for conventional ${ }^{1} \mathrm{H}$ NMR spectroscopy. The self-diffusion coefficients were measured using a simple Hahn spin-echo sequence and analyzing on the basis of the Stejskal equation $\ln E=-D \gamma^{2} g^{2} \delta^{2}(\Delta-\delta / 3),{ }^{24}$ where $E$ is the echo signal attenuation, $D$ is the self-diffusion coefficient, $\gamma$ is the gyromagnetic ratio, $g$ is the amplitude of the gradient pulses, $\delta$ is the duration of the gradient pulses, and $\Delta$ is the interval between the leading edges of the gradient pulses. The $g$ values used were in the range of $20 \mathrm{mT} \mathrm{m}^{-1}-300 \mathrm{mT} \mathrm{m}^{-1}$ at $75^{\circ} \mathrm{C}_{\text {and }} 20 \mathrm{mT} \mathrm{m}^{-1}-250 \mathrm{mT} \mathrm{m}^{-1}$ at $85^{\circ} \mathrm{C}, \delta$ was $8 \mathrm{~ms}$, and the value of $\Delta$ was $100 \mathrm{~ms}$. Separately, we prepared an equimolar mixture of $\mathrm{H}_{2} \mathrm{O}$ and $\mathrm{HTf}_{2} \mathrm{~N}$, a colorless transparent liquid at room temperature, and ${ }^{1} \mathrm{H}$ NMR was measured at room temperature to check the chemical state of $\mathrm{HTf}_{2} \mathrm{~N}$ and $\mathrm{H}_{2} \mathrm{O}$. In addition, we prepared a $18 \mathrm{C} 6$-added $\left[\mathrm{H}_{3} \mathrm{O}^{+} \cdot 18 \mathrm{C} 6\right] \mathrm{Tf}_{2} \mathrm{~N}$, an equimolar mixture of $18 \mathrm{C} 6$ (Kanto Chemical, as received) and $\left[\mathrm{H}_{3} \mathrm{O}^{+} \cdot 18 \mathrm{C} 6\right] \mathrm{Tf}_{2} \mathrm{~N}$. The 18C6-added $\left[\mathrm{H}_{3} \mathrm{O}^{+} \cdot 18 \mathrm{C} 6\right] \mathrm{Tf}_{2} \mathrm{~N}$ was a liquid at room temperature, which should contain free neutral $18 \mathrm{C} 6$. We performed ${ }^{1} \mathrm{H}$ and ${ }^{13} \mathrm{C}$ NMR measurements for the $18 \mathrm{C} 6$-added $\left[\mathrm{H}_{3} \mathrm{O}^{+} \cdot 18 \mathrm{C} 6\right] \mathrm{Tf}_{2} \mathrm{~N}$.

\section{Results and Discussion}

Figures 2 and 3 shows plots of echo signal attenuation on the basis of the Stejskal equation for $18 \mathrm{C} 6$ (red circles), $\mathrm{Tf}_{2} \mathrm{~N}^{-}$(blue circles), and $\mathrm{H}_{3} \mathrm{O}^{+}$(black circles) for $\left[\mathrm{H}_{3} \mathrm{O}^{+} \cdot 18 \mathrm{C} 6\right] \mathrm{Tf}_{2} \mathrm{~N}$ at $75^{\circ} \mathrm{C}$ and $85^{\circ} \mathrm{C}$, which was obtained reproducibly in different runs. As shown, the

(a)

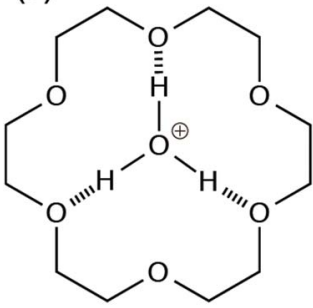

(b)

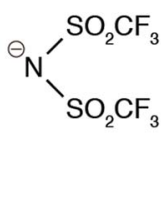

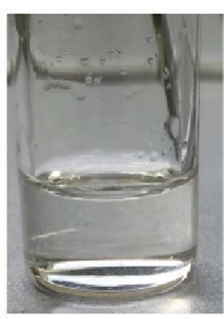




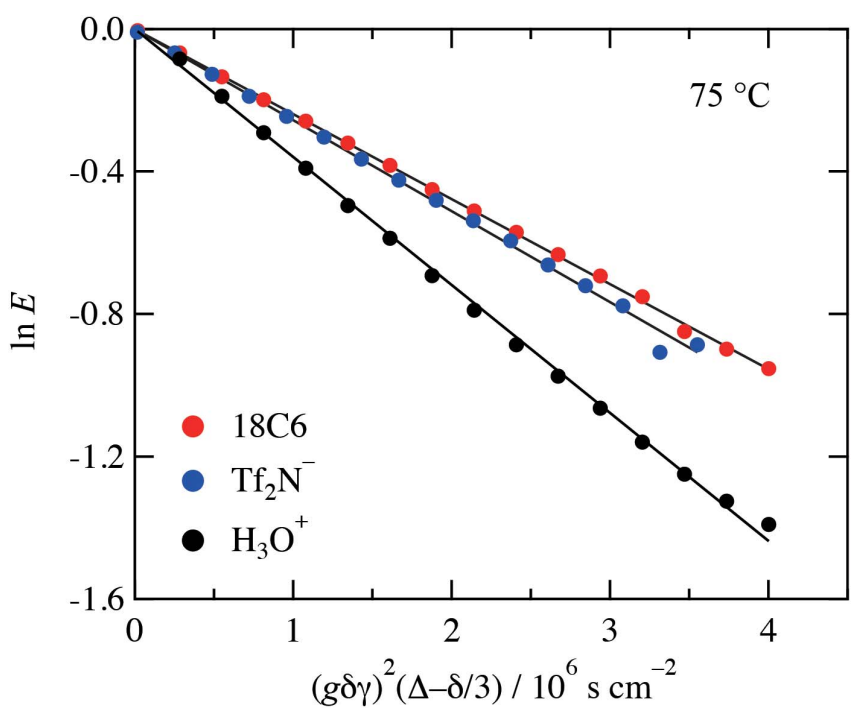

Figure 2. Plots of echo signal attenuation on the basis of the Stejskal equation for $18 \mathrm{C} 6$ (red circles), $\mathrm{Tf}_{2} \mathrm{~N}^{-}$(blue circles), and $\mathrm{H}_{3} \mathrm{O}^{+}$(black circles) at $75^{\circ} \mathrm{C}$.

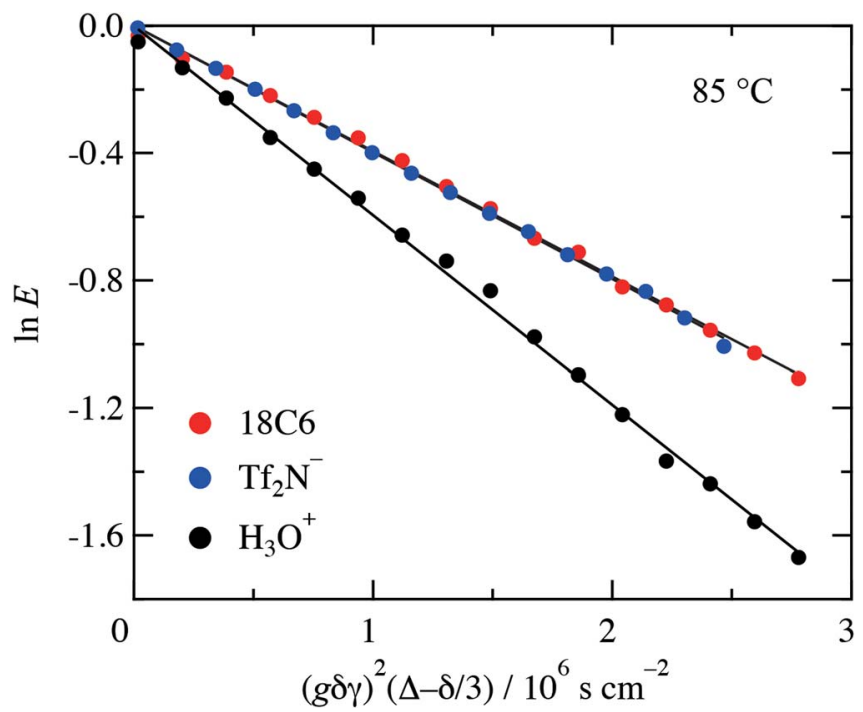

Figure 3. Plots of echo signal attenuation on the basis of the Stejskal equation for $18 \mathrm{C} 6$ (red circles), $\mathrm{Tf}_{2} \mathrm{~N}^{-}$(blue circles), and $\mathrm{H}_{3} \mathrm{O}^{+}$(black circles) at $85^{\circ} \mathrm{C}$.

plots have linear relationships. Table I lists the estimated values of self-diffusion coefficients for $\left[\mathrm{H}_{3} \mathrm{O}^{+} \cdot{ }_{18 \mathrm{C} 6}\right] \mathrm{Tf}_{2} \mathrm{~N}$. The values for the hydronium solvate IL are $10^{-7} \mathrm{~cm}^{2} \mathrm{~s}^{-1}$, almost the same order of magnitude as those for analogous lithium solvate ILs. ${ }^{8}$

The ionicity i.e. the degree of cation-anion dissociation of $\left[\mathrm{H}_{3} \mathrm{O}^{+} \cdot 18 \mathrm{C} 6\right] \mathrm{Tf}_{2} \mathrm{~N}$ has been estimated to be $\Lambda_{\text {imp }} / \Lambda_{\text {ideal }}=0.44$ from the Walden plot (molar conductivity $\Lambda_{\text {imp }}$ vs. fluidity $\eta^{-1}$ ). ${ }^{18}$ The ionicity of $\left[\mathrm{H}_{3} \mathrm{O}^{+} \cdot 18 \mathrm{C} 6\right] \mathrm{Tf}_{2} \mathrm{~N}$ can also be estimated as $\Lambda_{\text {imp }} / \Lambda_{\mathrm{NMR}}$ using the PGSE-NMR results. $\Lambda_{\mathrm{NMR}}$ can be calculated from the ionic self-

\section{Table I. Diffusion Coefficients of $\mathrm{H}_{3} \mathrm{O}^{+}, 18 \mathrm{C} 6$, and $\mathrm{Tf}_{2} \mathrm{~N}^{-}$at $75^{\circ} \mathrm{C}$} and $85^{\circ} \mathrm{C}$.

\begin{tabular}{llll}
$\begin{array}{l}\text { Temperature } \\
{\left[{ }^{\circ} \mathrm{C}\right]}\end{array}$ & $\begin{array}{l}D_{\mathrm{H} 3 \mathrm{O}+} \\
{\left[10^{-7} \mathrm{~cm}^{2} \mathrm{~s}^{-1}\right]}\end{array}$ & $\begin{array}{l}D_{18 \mathrm{C} 6} \\
{\left[10^{-7} \mathrm{~cm}^{2} \mathrm{~s}^{-1}\right]}\end{array}$ & $\begin{array}{l}D_{\mathrm{Tf} 2 \mathrm{~N}-} \\
{\left[10^{-7} \mathrm{~cm}^{2} \mathrm{~s}^{-1}\right]}\end{array}$ \\
\hline 75 & 3.6 & 2.4 & 2.6 \\
85 & 6.0 & 3.9 & 4.0
\end{tabular}

diffusion coefficients of cations $\left(D_{+}=D_{\mathrm{H} 3 \mathrm{O}+}\right)$ and anions $\left(D_{-}=\right.$ $D_{\text {Tf2N- }}$ ) measured by PGSE-NMR using the Nernst-Einstein equation $\Lambda_{\mathrm{NMR}}=F^{2} / R T\left(D_{+}+D_{-}\right)$where $F$ is the Faraday constant, $R$ is the gas constant, and $T$ is the absolute temperature. ${ }^{9}$ Using the data listed in Table I, we obtain $\Lambda_{\mathrm{NMR}}=2.0 \mathrm{~S} \mathrm{~cm}^{2} \mathrm{~mol}^{-1}$ at $75^{\circ} \mathrm{C}$ and 3.1 at $85^{\circ} \mathrm{C}$. Since the molar conductivity $\Lambda_{\text {imp }}$ is $1.05 \mathrm{~S} \mathrm{~cm}^{2} \mathrm{~mol}^{-1}$ at $75^{\circ} \mathrm{C}$ and $1.40 \mathrm{~S} \mathrm{~cm}^{2} \mathrm{~mol}^{-1}$ at $85^{\circ} \mathrm{C},{ }^{18}$ the ionicity $\Lambda_{\text {imp }} / \Lambda_{\mathrm{NMR}}$ is 0.53 at $75^{\circ} \mathrm{C}$ and 0.45 at $85^{\circ} \mathrm{C}$. The value is similar to $\Lambda_{\text {imp }} / \Lambda_{\text {ideal }}=0.44,{ }^{18}$ and also comparable to some lithium solvate ILs. ${ }^{9,10}$

In Figs. 2 and 3 the gradients of the fitted lines, which according to the Stejskal equation are proportional to diffusion coefficients, ${ }^{24}$ are almost the same for $18 \mathrm{C} 6$ and $\mathrm{Tf}_{2} \mathrm{~N}^{-}$, while that for $\mathrm{H}_{3} \mathrm{O}^{+}$is significantly larger. The ratio of the diffusion coefficient $D_{\mathrm{H} 3 \mathrm{O}+} / D_{18 \mathrm{C} 6}$ is 1.5 , indicating that protons of hydronium ions move faster than $18 \mathrm{C} 6$ ligands, indicating ligand exchange conduction of solute ions. Notably, the activation energy estimated from Arrhenius plots ${ }^{18}$ is $28.0(6) \mathrm{kJ}$ $\mathrm{mol}^{-1}$ for ionic conduction, certainly lower than $28.9(1) \mathrm{kJ} \mathrm{mol}^{-1}$ for viscous flow. Thus, we consider that a ligand exchange conduction mechanism exists although vehicle mechanism is dominant in the hydronium solvate IL. In solvate ILs, by contrast, metal ions (such as lithium ions) and the ligands move together: a vehicle mechanism has been suggested because the ratio is identical within the experimental error, i.e. $D_{\mathrm{Li}+} / D_{18 \mathrm{C} 6}=1.0-1.1 .^{8-10}$ Therefore, a line should be drawn between the hydronium solvate IL and the other reported solvate ILs. At this point, however, we cannot conclude whether $\mathrm{H}^{+}$or $\mathrm{H}_{3} \mathrm{O}^{+}$ moves since we have not measured diffusion coefficients of oxygen $\left(D_{\mathrm{O}}\right)$ of $\mathrm{H}_{3} \mathrm{O}^{+}$. If $\mathrm{H}^{+}$diffuse (much) faster than oxygen which is the mass center of the hydronium $\left(D_{\mathrm{H} 3 \mathrm{O}+} / D_{\mathrm{O}}>>1\right)$, we can say the proton has hopping conduction where the $\mathrm{H}_{3} \mathrm{O}^{+}$cation unit would relay one of its protons to an adjacent molecule upon acceptance of a proton. Given $D_{\mathrm{H} 3 \mathrm{O}+} / D_{\mathrm{O}} \sim 1$, migration of $\mathrm{H}_{3} \mathrm{O}^{+}$as a whole (vehicular diffusion of proton) should occur, just like the proton in acidic solution as observed by Kreuer et al. ${ }^{25}$

Clearly, the presence of hydrogen bonding, which should be related to the observed ligand exchange conduction, differentiates the hydronium solvate IL from all metal ion solvate ILs previously reported. In protic ILs, Grotthuss-like $\mathrm{H}^{+}$transfer (i.e. proton hopping) takes place in the presence of neutral molecules. For example, a mixture of $\mathrm{HTf}_{2} \mathrm{~N}$ and excess (more than equimolar) imidazole molecules shows proton hopping conduction, revealed by the fact that protons move faster than imidazole molecules. ${ }^{5,16,17}$ Although the conductivity is high in the $\mathrm{HTf}_{2} \mathrm{~N}$-imidazole mixture, the volatility of neutral imidazole molecules prevents their use at high temperature. Notably, in the equimolar mixture of $\mathrm{HTf}_{2} \mathrm{~N}$-imidazole, a protic IL composed of $\left[\mathrm{ImH}^{+}\right]$cation and $\mathrm{Tf}_{2} \mathrm{~N}^{-}$anion, hopping conduction does not occur (diffusion coefficient ratio $D_{\mathrm{H}+} / D_{\mathrm{Im}}=1$ ). In our hydronium solvate IL, however, the faster transfer of $\mathrm{H}_{3} \mathrm{O}^{+}$ions as a whole (or faster transfer of $\mathrm{H}^{+}$) than 18C6 ligands occurs with negligible number of neutral molecules. In other words, an experimentally "equimolar" mixture can contain tiny-less than $1 \%$-amount of excess neutral molecules, but such possible neutral molecules did not cause a hopping conduction for $\mathrm{HTf}_{2} \mathrm{~N}$-imidazole but for $\mathrm{H}_{2} \mathrm{O}-18 \mathrm{C} 6-\mathrm{HTf}_{2} \mathrm{~N}$.

It is noteworthy that before and after the PGSE-NMR measurements the water content of the $\left[\mathrm{H}_{3} \mathrm{O}^{+} \cdot 18 \mathrm{C} 6\right] \mathrm{Tf}_{2} \mathrm{~N}$ sample was same, thus the sample composition did not change (neither contamination of extra water nor sublimation of $\mathrm{HTf}_{2} \mathrm{~N}$ component was detected) during the measurements, strongly indicating that the ligand exchange conduction is intrinsic to stoichiometric $\left[\mathrm{H}_{3} \mathrm{O}^{+} \cdot 18 \mathrm{C} 6\right] \mathrm{Tf}_{2} \mathrm{~N}$. The estimated transference number of cation $t_{+}$, using the value of $D_{\mathrm{H} 3 \mathrm{O}+}$ and $D_{\text {Tf2N- }}$, was as large as 0.58 at $75^{\circ} \mathrm{C}$ and 0.60 at $85^{\circ} \mathrm{C}$. The obtained $t_{+}$is comparable to those of some solvate ILs $(0.44-0.61)^{9,10}$ and slightly smaller than those of the $\mathrm{Im}-\mathrm{HTf}_{2} \mathrm{~N}$ protic ILs $(0.66-0.78) .{ }^{17}$ The proton conductivity, i.e., the product of $t_{+}$and ionic conductivity, can be obtained as $1.37 \mathrm{mS} \mathrm{cm}{ }^{-1}$ at $75^{\circ} \mathrm{C}$ and $1.83 \mathrm{mS} \mathrm{cm}^{-1}$ at $85^{\circ} \mathrm{C}$.

The ligand exchange conduction without intrinsically volatile neutral molecules is fascinating because the concept could enable high temperature application with high conductivity. Consequently, in terms of the ligand exchange conduction mechanism, the hydronium solvate IL should be distinguished from all protic ILs previously 


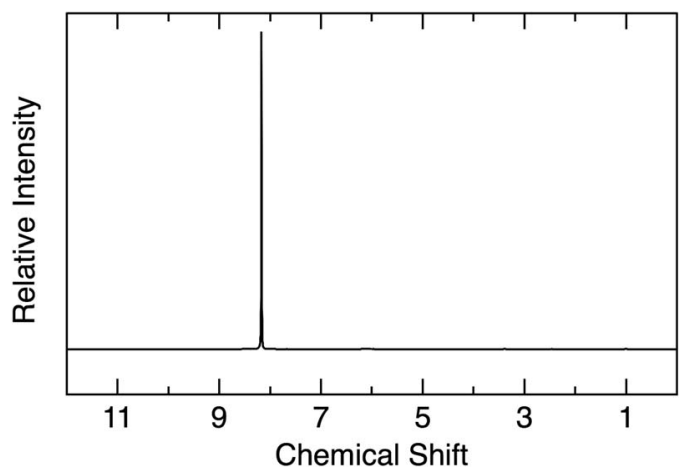

Figure 4. ${ }^{1} \mathrm{H}$ NMR spectrum for $1: 1$ mixture of $\mathrm{H}_{2} \mathrm{O}$ and $\mathrm{HTf}_{2} \mathrm{~N}$ obtained at $30^{\circ} \mathrm{C}$, showing only one singlet due to absence of neutral $\mathrm{H}_{2} \mathrm{O}$ (see text for details).

reported. The conduction relates to the evolution of a hydrogen bonding network in $\left[\mathrm{H}_{3} \mathrm{O}^{+} \cdot 18 \mathrm{C} 6\right] \mathrm{Tf}_{2} \mathrm{~N}$. In the hydronium solvate IL there are three $\mathrm{O}-\mathrm{H}$ bonds in $\mathrm{H}_{3} \mathrm{O}^{+}$and three hydrogen bonds with $18 \mathrm{C} 6$ (Fig. 1a), while in $\left[\mathrm{ImH}^{+}\right] \mathrm{Tf}_{2} \mathrm{~N}$ there seems to be only one $\mathrm{N}-\mathrm{H}$ bond. Thus, we consider that the dense hydrogen bonding network causes the unusual conduction mechanism, which does not need the help of neutral molecules.

A further insight for possible origin of the foregoing ligand exchange conduction of the hydronium solvate IL was speculated from the thermogravimetric analysis result. ${ }^{18}$ The temperature of a $5 \%$ mass loss for the hydronium solvate $\mathrm{IL}$ is $132^{\circ} \mathrm{C}$ at a heating rate of $5 \mathrm{~K}$ $\mathrm{min}^{-1}$. Although the ligand (i.e., crownether and glyme) and/or coordinated cation $\left(\mathrm{Li}^{+}, \mathrm{Na}^{+}, \mathrm{K}^{+}\right.$, etc) is different, this temperature seems much lower than those for previous solvate ILs with $\mathrm{Tf}_{2} \mathrm{~N}^{-}$anion (190-220 $\mathrm{C}$; heating rate: $\left.\left.10 \mathrm{~K} \mathrm{~min}^{-1}\right)\right)^{9,11}$ In this respect, although several chemical characterization results including infrared spectra revealed that neutral $18 \mathrm{C} 6$ molecules are negligible, ${ }^{18}$ i.e. $\left[\mathrm{H}_{3} \mathrm{O}^{+} \cdot 18 \mathrm{C} 6\right]$ solvate is thermodynamically "stable" as well as the previous solvate ILs, the hydronium solvate IL is kinetically "labile". In other words, the kinetic constant for ligand exchange i.e., $\mathrm{H}_{2} \mathrm{O}+18 \mathrm{C} 6+\mathrm{HTf}_{2} \mathrm{~N}$ $\rightleftharpoons\left[\mathrm{H}_{3} \mathrm{O}^{+} .18 \mathrm{C} 6\right] \mathrm{Tf}_{2} \mathrm{~N}$ is very fast, while the equilibrium shift to the right. Thus, the lability of solvation in $\mathrm{H}_{2} \mathrm{O}+18 \mathrm{C} 6+\mathrm{HTf}_{2} \mathrm{~N} \rightleftharpoons$ $\left[\mathrm{H}_{3} \mathrm{O}^{+}\right.$. 18C6]Tf ${ }_{2} \mathrm{~N}$ could help the fast(er) transfer of $\mathrm{H}_{3} \mathrm{O}^{+}$or $\mathrm{H}^{+}$, and accelerate mass loss at lower temperature due to the volatile nature of $\mathrm{H}_{2} \mathrm{O}, 18 \mathrm{C} 6$, and $\mathrm{HTf}_{2} \mathrm{~N}$ compared to the previous solvate ILs. Since the inert solvate ILs prohibit ligand exchange conduction and allow only vehicle conduction, we propose that it is the labile solvation of the hydronium solvate IL that enables the ligand exchange conduction. Additionally, if the solvation ability of hydronium solvate IL were inert, the active proton of $\mathrm{H}_{3} \mathrm{O}^{+}$could not move out of the ligand. Also, the strong acidity of $\left[\mathrm{H}_{3} \mathrm{O}^{+} \cdot 18 \mathrm{C} 6\right] \mathrm{Tf}_{2} \mathrm{~N}$, which we reported previously, ${ }^{18}$ would not appear.

We also note that, without $18 \mathrm{C} 6$, i.e. an equimolar mixture of $\mathrm{H}_{2} \mathrm{O}$ and $\mathrm{HTf}_{2} \mathrm{~N}$ shows very different nature from that of $\left[\mathrm{H}_{3} \mathrm{O}^{+} \cdot 18 \mathrm{C} 6\right] \mathrm{Tf}_{2} \mathrm{~N}$. It has been suggested by infrared experiments (for 1:1 $\mathrm{H}_{2} \mathrm{O}$ and $\mathrm{HTf}_{2} \mathrm{~N}$ in an organic solution) and ab initio calculations (for one $\mathrm{H}_{2} \mathrm{O}$ and one $\mathrm{HTf}_{2} \mathrm{~N}$ molecules in vacuum) that, the proton of $\mathrm{HTf}_{2} \mathrm{~N}$ remains associated in equimolar mixture of $\mathrm{H}_{2} \mathrm{O}$ and $\mathrm{HTf}_{2} \mathrm{~N}{ }^{18,26,27}$ However, bulk system of $1: 1 \mathrm{H}_{2} \mathrm{O}$ and $\mathrm{HTf}_{2} \mathrm{~N}$ without any solvents has not experimentally studied so far. We have checked ${ }^{1} \mathrm{H}$ NMR of the equimolar mixture of $\mathrm{H}_{2} \mathrm{O}$ and $\mathrm{HTf}_{2} \mathrm{~N}$ (without $18 \mathrm{C} 6$ or any other solvents). As a result, only one singlet was observed at $8.18 \mathrm{ppm}$ (shown in Fig. 4), evidencing that neutral $\mathrm{H}_{2} \mathrm{O}$-usually at $3.3 \mathrm{ppm}$ for pure water- is absent and $\mathrm{H}_{2} \mathrm{O}$ has reacted with $\mathrm{HTf}_{2} \mathrm{~N}$. However, the obtained chemical shift was much lower than those of molten $\left[\mathrm{H}_{3} \mathrm{O}^{+} \cdot 18 \mathrm{C} 6\right] \mathrm{Tf}_{2} \mathrm{~N}(10.85 \mathrm{ppm})^{18}$ and $\mathrm{HTf}_{2} \mathrm{~N}$ dissolved in acetone $(10.42 \mathrm{ppm}){ }^{28}$ The value is very close to the reported value of $\mathrm{HTf}_{2} \mathrm{~N}$ dissolved in $\mathrm{CFCl}_{3},(7.92 \mathrm{ppm}){ }^{28}$ Since acetone can dissociate $\mathrm{HTf}_{2} \mathrm{~N}$ and $\mathrm{CFCl}_{3}$ cannot, the obtained results for 1:1 mixture of $\mathrm{H}_{2} \mathrm{O}$ and $\mathrm{HTf}_{2} \mathrm{~N}$ may suggest that $\mathrm{HTf}_{2} \mathrm{~N}$ protonates $\mathrm{H}_{2} \mathrm{O}$ to be
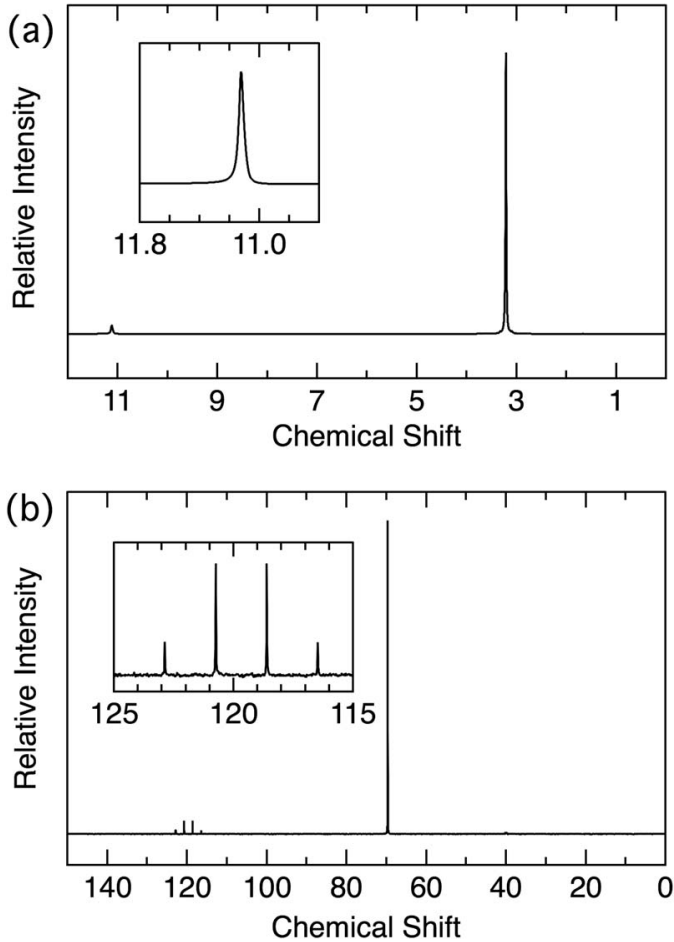

Figure 5. (a) ${ }^{1} \mathrm{H}$ and $(b){ }^{13} \mathrm{C}$ NMR spectra for $1: 1$ mixture of $18 \mathrm{C} 6$ and $\left[\mathrm{H}_{3} \mathrm{O}^{+} \cdot 18 \mathrm{C} 6\right] \mathrm{Tf}_{2} \mathrm{~N}$ obtained at $30^{\circ} \mathrm{C}$, showing chemical shifts quite similar to those of $\left[\mathrm{H}_{3} \mathrm{O}^{+} \cdot 18 \mathrm{C} 6\right] \mathrm{Tf}_{2} \mathrm{~N}$ (see text for details). Insets show enlarged plots.

$\mathrm{H}_{3} \mathrm{O}^{+} \cdot \mathrm{Tf}_{2} \mathrm{~N}$ but its degree of dissociation (i.e. ionicity) is low. Consequently, an equimolar mixture of $\mathrm{H}_{2} \mathrm{O}$ and $\mathrm{HTf}_{2} \mathrm{~N}$ shows very different nature from that of $\left[\mathrm{H}_{3} \mathrm{O}^{+} \cdot 18 \mathrm{C} 6\right] \mathrm{Tf}_{2} \mathrm{~N}$ (e.g. the ionicity is as large as $0.44-0.53$ ). Therefore, the possible labile solvation of $18 \mathrm{C} 6$ or local presence/absence of $18 \mathrm{C} 6$ can sizably affect local physicochemical properties of $\left[\mathrm{H}_{3} \mathrm{O}^{+} \cdot 18 \mathrm{C} 6\right] \mathrm{Tf}_{2} \mathrm{~N}$.

To verify the labile solvation, we mixed $\left[\mathrm{H}_{3} \mathrm{O}^{+} \cdot 18 \mathrm{C} 6\right] \mathrm{Tf}_{2} \mathrm{~N}$ with equimolar amount of neat $18 \mathrm{C} 6$. The mixture was a liquid at room temperature, while $\left[\mathrm{H}_{3} \mathrm{O}^{+} \cdot 18 \mathrm{C} 6\right] \mathrm{Tf}_{2} \mathrm{~N}$ was a solid at such temperature. ${ }^{18}$ As shown in Fig. 5a, the ${ }^{1} \mathrm{H}$ NMR spectra of the 18C6-added $\left[\mathrm{H}_{3} \mathrm{O}^{+} \cdot 18 \mathrm{C} 6\right] \mathrm{Tf}_{2} \mathrm{~N}$ only showed two kinds of singlets for $\mathrm{H}_{3} \mathrm{O}^{+}(11.12 \mathrm{ppm})$ and $18 \mathrm{C} 6(3.22 \mathrm{ppm})$, similar to the case of $\left[\mathrm{H}_{3} \mathrm{O}^{+} \cdot 18 \mathrm{C} 6\right] \mathrm{Tf}_{2} \mathrm{~N}(10.85 \mathrm{ppm}$ and $3.23 \mathrm{ppm}){ }^{18} \mathrm{In}$ addition, the peak area ratio for $\mathrm{H}_{3} \mathrm{O}^{+}: 18 \mathrm{C} 6$ was $1: 16(=3: 48)$, which agrees the theoretical ratio of $\mathrm{H}_{3} \mathrm{O}^{+}: 2 \mathrm{C}_{12} \mathrm{H}_{24} \mathrm{O}_{6}$ for the $18 \mathrm{C} 6$ added $\left[\mathrm{H}_{3} \mathrm{O}^{+} \cdot 18 \mathrm{C} 6\right] \mathrm{Tf}_{2} \mathrm{~N}$. The ${ }^{13} \mathrm{C}$ NMR spectra showed a singlet (69.69 ppm) for $18 \mathrm{C} 6$ and a quartet (122.88 ppm, $120.75 \mathrm{ppm}$, $118.61 \mathrm{ppm}, 116.48 \mathrm{ppm}$; peak area ratio was $1: 2: 2: 1$ ) for $\mathrm{Tf}_{2} \mathrm{~N}^{-}$, similar to the case of $\left[\mathrm{H}_{3} \mathrm{O}^{+} \cdot 18 \mathrm{C} 6\right] \mathrm{Tf}_{2} \mathrm{~N}(69.37 \mathrm{ppm}$ for $18 \mathrm{C} 6$, and $122.89 \mathrm{ppm}, 120.76 \mathrm{ppm}, 118.62 \mathrm{ppm}, 116.50 \mathrm{ppm}$ for $\left.\mathrm{Tf}_{2} \mathrm{~N}^{-}\right){ }^{18}$ Also, the peak area ratio was 12:1, in good agreement with the stoichiometric one (see Fig. 5b). These results clarify that the solvating and un-solvating 18C6 cannot be detected independently within the NMR chemical shift timescale, which strongly suggest the fast kinetic exchange of the solvating and un-solvating 18C6, or labile solvation of $\left[\mathrm{H}_{3} \mathrm{O}^{+} \cdot 18 \mathrm{C} 6\right] \mathrm{Tf}_{2} \mathrm{~N}$.

Similar ${ }^{1} \mathrm{H}$ NMR results-undistinguishable peaks for solvated and un-solvated ligands within the NMR chemical shift timescale-have been reported for a $\mathrm{LiTf}_{2} \mathrm{~N}$-glyme system, which also revealed a very quick ligand exchange between solvating and un-solvating glymes. ${ }^{10}$ In this case, however, a ligand exchange conduction mechanism is not proposed for the bulk conduction of solvate IL $\left[\mathrm{Li}^{+} \cdot \operatorname{glyme}\right] \mathrm{Tf}_{2} \mathrm{~N}$, but is proposed only when an external electric field is applied to induce interfacial electrochemical reactions of $\left[\mathrm{Li}^{+} \cdot\right.$ glyme $]$ cations. Therefore, we propose that the difference between coordinated cation 
$\left(\mathrm{Li}^{+}\right.$and $\left.\mathrm{H}_{3} \mathrm{O}^{+}\right)$may allow the bulk ligand exchange conduction for $\left[\mathrm{H}_{3} \mathrm{O}^{+}\right.$. 18C6] $\mathrm{Tf}_{2} \mathrm{~N}$ without any external electric field, which can be attributed to the labile solvation. We also note that the labile solvation should explain why $\left[\mathrm{H}_{3} \mathrm{O}^{+} \cdot 18 \mathrm{C} 6\right] \mathrm{Tf}_{2} \mathrm{~N}$ is highly acidic as we reported previously, ${ }^{18}$ despite the large stability constants for $\left[\mathrm{H}_{3} \mathrm{O}^{+} \cdot 18 \mathrm{C} 6\right] .{ }^{23}$

\section{Conclusions}

We revealed that $\left[\mathrm{H}_{3} \mathrm{O}^{+} \cdot 18 \mathrm{C} 6\right] \mathrm{Tf}_{2} \mathrm{~N}$, the first example of hydronium solvate $\mathrm{IL}$, is highly proton-conductive (proton transference number $t_{\text {proton }}=0.60$ ) and shows a ligand exchange conduction mechanism. Ligand exchange conduction without inducing external electric field has not been reported for known metal-cation solvate ILs. The ligand exchange conduction occurs without sizable number of neutral molecules, suggesting a hopping mechanism different from those of protic ILs that require sizable number of neutral molecules. Further study to determine if the carrier is $\mathrm{H}^{+}$or $\mathrm{H}_{3} \mathrm{O}^{+}$, by measuring diffusion coefficients of oxygen $\left(D_{\mathrm{O}}\right)$ of $\mathrm{H}_{3} \mathrm{O}^{+}$, is of special interest.

\section{Acknowledgments}

We thank Dr. Naoya Nishi for fruitful discussion. This work was supported financially by Grants-in-Aid for Scientific Research (A) (No. 16H02411) from the Japan Society for the Promotion of Science. A. K. also thanks (i) the Joint Usage/Research Program on Zero-Emission Energy Research, Institute of Advanced Energy, Kyoto University (ZE30A-1), (ii) Kyoto University Education and Research Foundation, and (iii) FY 2017 Kyoto University Research Development Program ISHIZUE, for their financial supports.

\section{ORCID}

Atsushi Kitada (D) https://orcid.org/0000-0002-4387-8687 Kuniaki Murase (D) https://orcid.org/0000-0002-7564-9416

\section{References}

1. T. Welton, Chem. Rev., 99, 2071 (1999)

2. K. Fujita, K. Murata, M. Masuda, N. Nakamura, and H. Ohno, RSC Adv., 2, 4018 (2012).

3. T. L. Greaves and C. J. Drummond, Chem. Rev., 115, 11379 (2015).

4. P. A. Hunt, C. R. Ashworth, and R. P. Matthews, Chem. Soc. Rev., 44, 1257 (2015).

5. M. Armand, F. Endres, D. R. MacFarlane, H. Ohno, and B. Scrosati, Nat. Mater., 8, 621 (2009).

6. A. S. Amarasekara, Chem. Rev., 116, 6133 (2016).

7. C. A. Angell, Y. Ansari, and Z. Zhao, Faraday Discuss., 154, 9 (2012).

8. T. Mandai, K. Yoshida, K. Ueno, K. Dokko, and M. Watanabe, Phys. Chem. Chem. Phys., 16, 8761 (2014)

9. K. Ueno, K. Yoshida, M. Tsuchiya, N. Tachikawa, K. Dokko, and M. Watanabe, $J$. Phys. Chem. B, 116, 11323 (2012).

10. K. Yoshida, M. Nakamura, Y. Kazue, N. Tachikawa, S. Tsuzuki, S. Seki, K. Dokko, and M. Watanabe, J. Am. Chem. Soc., 133, 13121 (2011).

11. T. Mandai, S. Tsuzuki, K. Ueno, K. Dokko, and M. Watanabe, Phys. Chem. Chem. Phys., 17, 2838 (2015)

12. Y. Song, H. Jing, B. Li, and D. Bai, Chem. Eur. J., 17, 8731 (2011).

13. A. J. Pawlak and M. L. Dietz, Sep. Sci. Technol., 49, 2847 (2014).

14. Y. Song, C. Cheng, and H. Jing, Chem. Eur. J., 20, 12894 (2014).

15. A. Kitada, D. Ishikawa, K. Fukami, and K. Murase, J. Electrochem. Soc., 164, H5119 (2017).

16. A. Noda, M. A. B. H. Susan, K. Kudo, S. Mitsushima, K. Hayamizu, and M. Watanabe, J. Phys. Chem. B, 107, 4024 (2003).

17. M. L. Hoarfrost, M. Tyagi, R. A. Segalman, and J. A. Reimer, J. Phys. Chem. B, 116, 8201 (2012).

18. A. Kitada, S. Takeoka, K. Kintsu, K. Fukami, M. Saimura, T. Nagata, and K. Murase, J. Electrochem. Soc., 165, H121 (2018).

19. G. S. Heo and R. A. Bartsch, J. Org. Chem., 47, 3557 (1982).

20. R. Chénevert, A. Rodrigue, P. Beauchesne, and R. Savoie, Can. J. Chem., 62, 2293 (1984).

21. R. Chenevert and A. J. Rodrique, Chem. Educ., 61, 465 (1984).

22. R. Chênevert, D. Chamberland, M. Simard, and F. Brisse, Can. J. Chem., 67, 32 (1989).

23. I. M. Kolthoff, W-J. Wang, and M. K. Chantooni Jr., Anal. Chem., 55, 1202 (1983).

24. W. S. Price, Concepts Magn. Reson., 9, 299 (1997).

25. T. Dippel and K. D. Kreuer, Solid State Ionics, 46(1-2), 3 (1991).

26. E. S. Stoyanov, K.-C. Kim, and C. A. Reed, J. Phys. Chem. A, 108, 9310 (2004).

27. J. K. Clark, S. J. Paddison, M. Eikerling, M. Dupuis, and T. A. Zawodzinski Jr., J. Phys. Chem. A, 116, 1801 (2012).

28. J. Foropoulos Jr. and D. D. DesMarteau, Inorg. Chem., 23, 3720 (1984). 